\title{
Unchiku Generation with Moving Illustration Using Kabuki Knowledge
}

\author{
Jumpei Ono \\ Faculty of Software and Information Technology, Aomori University, \\ 2-10-1, Seishincho, Edogawa, 134-0087, Japan \\ Miku Kawai \\ Faculty of Software and Information Science, Iwate Prefectural University, \\ 152-52, Sugo, Takizawa, 020-0693, Japan \\ Takashi Ogata \\ Faculty of Software and Information Science, Iwate Prefectural University, \\ 152-52, Sugo, Takizawa, 020-0693, Japan \\ E-mail:j.ono@aomori-u.ac.jp,g031p035@s.iwate-pu.ac.jp \\ t-ogata@iwate-pu.ac.jp
}

\begin{abstract}
We developed an explanation-generation system based on narratology. We also developed an unchiku generation system as an application. After creating a prototype, we then considered a new system that would combine the unchiku generation system with an animation system. We implemented the animation system in our kabuki study. This paper considers the possibilities of the unchiku generation system.
\end{abstract}

Keywords: Kyōganoko Musume Dōjōji, moving illustration, narrative generation, unchiku.

\section{Introduction}

Drawing on the foundations of narratology and literary theory, systematized thought, and philosophy, we developed a program that generates narratives. ${ }^{1,2} \mathrm{We}$ then designed a mechanism for unchiku generation ${ }^{3,4}$ for integration into the narrative generation system.

We study explanation generation in the context of narratology. Narrative means not just the progression of a plot but also the surplus or excess exposition that can interfere with its rapid progress. In Gérard Genette's theories on narrative discourse, ${ }^{5,6}$ such techniques-for example, explanation and description-are seen as halting the temporal progression of the narrative. Explanation is the act of justifying various objects or events in a story (e.g., characters, setting, physical objects, abstract ideas, etc.) and their relationships; it often clarifies but remains separate from the progress and development of the storyline. The unchiku is a form of explanation that uses deep content to share knowledge or teach a lesson to a disinterested audience.

We also study kabuki narrative generation by comprehensively examining the structure, methods, and techniques of narrative in kabuki to refine our narrative generation system.

In our research system of narrative generation, ${ }^{1,2}$ the kabuki form is central to the method of narrative generation. We have placed the "work performed on stage" at the center and presented a list of its multiple components, ${ }^{7}$ extracted representative kabuki methods and techniques, and analyzed them in detail through prototypes $^{8,9}$ to further our narratological research in the kabuki tradition. ${ }^{10}$

We focused our analysis specifically on the kabuki dance Kyōganoko Musume Dōjōji, ${ }^{1-14}$ a later tale of the legend of Dōjōji that has been performed by many 
excellent onnagata (male actors playing female characters) since ancient times with new content added beyond the original legend. In our earlier work ${ }^{13,14}$ we used a system we developed called KOSERUBE, ${ }^{15}$ an animation tool for a story generation system, to create visual representations of the structure of the stage performance.

Other researchers have also built narrative generation systems based on the work of Pablo Gervás ${ }^{16}$ as part of the broader computational creativity movement that focuses on narrative applications in the field of robotics-for example, developing socially assistive robots with a narrative approach. ${ }^{17}$ Our particular research proposes a method of combining moving illustrations on the screen as a tool to inform users of unchiku. In this paper, story means the combined storyline and explanation, and the unchiku is the detailed information within the explanation.

There are many possible ways of using moving illustrations. We previously described our approach to one of these methods. ${ }^{13,14}$ In this paper, we examine that method's opposite: using images as explanations of texts. The overall concept of using pictures to explain the text is not new-encyclopedias and dictionaries have done this for centuries. However, this paper proposes the use of an automated animation tool to explain Kyogganoko Musume Dōjōji text.

In describing our prototype, we will clarify the concept and examine the issues and usage for the future. Our final goal is to integrate the explanation using video and the explanation of the video and to treat each as a function.

\section{Two Background Systems}

This section describes the animation system of the Kyōganoko Musume Dōjōji and the unchiku generation system. The modules of the prototype system use these two systems.

\subsection{The Animation System of the Kyōganoko Musume Dōjōji}

The first system is an animation system that depicts the stage performance structure. The data on Kyoganoko Musume Dōjojii used in this study came from our analysis so far. First, we focused on three items in the stage structure table-kokoro (core conceptual theme), furi (performance), and lyrics - that are described in Musume ${ }^{D o j o j i .}{ }^{1}$ We analyzed the elements in the stage structure table to build a storyboard. ${ }^{2}$

Referring to an analysis of Musume Dōjōji ${ }^{18}$ by Tamotsu Watanabe, a contemporary kabuki researcher and critic, we conducted a detailed analysis of the "stage performance structure" (narrative outline) of the play. The main components were the characters, background (stage set), music (instruments, performers, and genres), lyrics, dialogue, and the core spiritual themes of each scene.

Musume Dōjōji recounts the legend of Kiyohime and Anchin. In the legend, a young woman named Kiyohim falls in love with Anchin, a Buddhist monk, who rejects her. She turns into a snake and kills him. After more than a thousand years of telling this story through oral histories, picture scrolls, and other reading materials, the story has transformed into the present-day Kyoganoko Musume Dōjōji. Our narrative generation system is based on its Kabuki dance. We summarized the stage performance structure of Kyōganoko Musume Dōjoji in an analysis table and created a storyboard to develop our animation system.

We have previously written about our analysis of the stage performance structure of Kyōganoko Musume Dōjojii in detail ${ }^{11}$ and how we developed an animation system to express it called KOSERUBE, a folktale-style story generation system. ${ }^{15}$ With the system, users can select folktales and characters, and it automatically generates a story based on the selections. The system also generates an animation for the generated story, displaying the lyrics at the bottom of the screen; the background and characters change from scene to scene. Our animation system can also reproduce and generate music $^{12}$ based on the score of Syamisen Bunkahu Nagauta Kyōganoko Musume Dōjōji ${ }^{19}$ and recorded music stored in the system. ${ }^{20}$ The prototype system uses the analysis of Kyoganoko Musume Dojjoji, the story of Dōjojji Enki, and the attributes of the characters. Details are given in Section 3.1.

\subsection{The Unchiku Generation System}

The second system is an unchiku generation system. Unchiku means deeply preserved knowledge. Unchiku wo tareru (to tilt one's unchiku) means putting all your energy into that knowledge. In recent years, unchiku is often used to mean "trivia." However, unchiku wo tareru (to draw upon one's unchiku) and unchiku wo hikerakasu (to show off one's unchiku) mean showing off knowledge learned from undesirable situations. The story uses unchiku as one of its rhetorical techniques. A story has a rhetorical device that slow or stop the progress of the plot in the story by, for example, pausing to describe something in the story. For the characters in the story, "tilting one's unchiku" is the act of explaining something 
(e.g., an object, character, setting, or event, etc.) in detail. We have developed the unchiku generation system with the aim of establishing a "starting point and means for systematically collecting, accumulating, and utilizing kabuki knowledge."3,4

As mentioned earlier, unchiku is one rhetorical technique used in Musume Dōjōji. We have previously discussed various aspects of narrative discourse, including the "distance" between the storyteller and the story, ${ }^{6}$ based on the structuralist theories proposed by Genette. ${ }^{5}$ We position unchiku as an explanation for excess quantities verbosity. Originally, we extracted information from Wikipedia to develop our unchiku generation module, ${ }^{3,4}$ but we have refined our unchiku generation in the prototype system. Details are given in Section 3.2.

\section{Unchiku Generation with Moving Illustration}

Combining the unchiku generation with the insertion of moving illustrations tells the story as animation. Our goals for the prototype system were (1) to clarify the system image and (2) to analyze plans and issues for future full-scale development. This section describes the data structure and the system.

\subsection{Knowledge Structure for the Proposed System}

The prototype system limits the text and animation material of the unchiku to Kyōganoko Musume Dōjōji. For this reason, we have provided English supplements to the actual data and generated examples for this paper.

Figures 1 and 2 show the knowledge for unchiku generation: Figure 1 relates to elements in the story; Figure 2 relates to the scene of Kyogganoko Musume Dojjoji associated with the knowledge listed in Figure 1. Figure 3 shows the story used in this paper.

Fig. 1. The unchiku knowledge of the Dōjōji

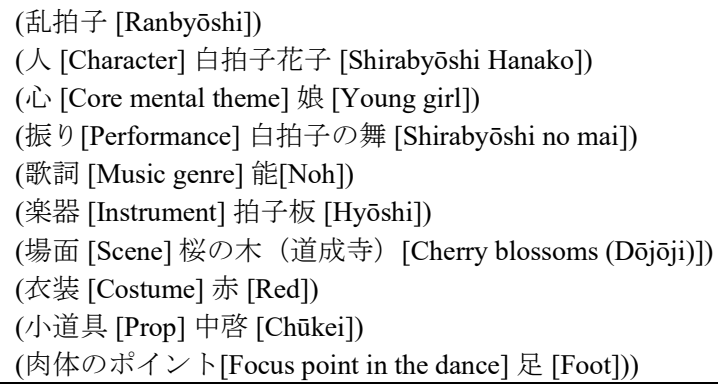

Fig. 2. The unchiku knowledge of the Kyōganoko Musume Dōjōji

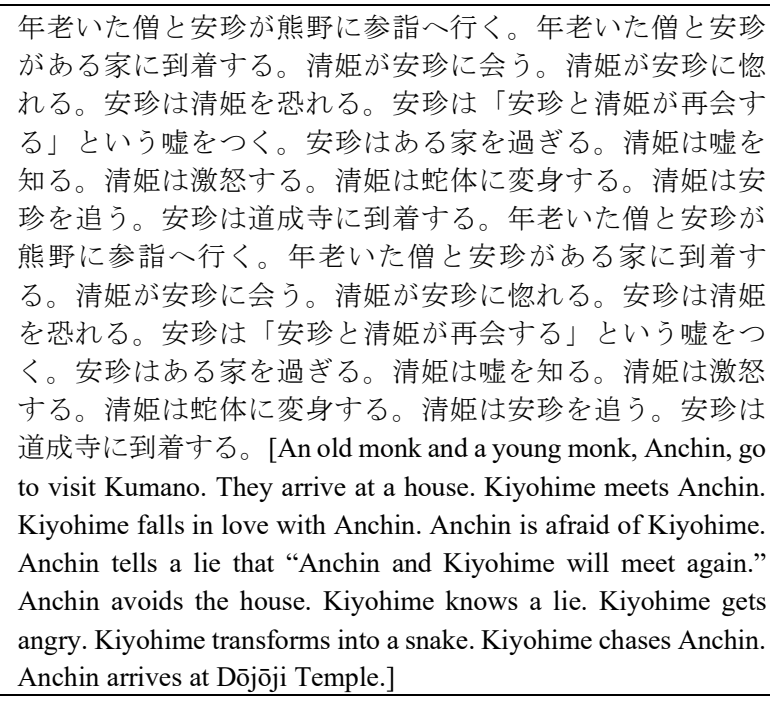

Fig. 3. The Musume Dōjōji story

\subsection{Prototype System}

In the prototype system, the unchiku generation is supplemented by inserting moving illustrations to produce animation: the story and unchiku appear as text with animation in the middle of the sentences associated with the words. Figure 4 shows the process of the system and its two modules. The first module creates a story with the unchiku. The other generates animations keyed to parts of the generated story. The system also contains a textual knowledge base and an image knowledge base. The system receives a story, then animates the story and the knowledge contained in it. 


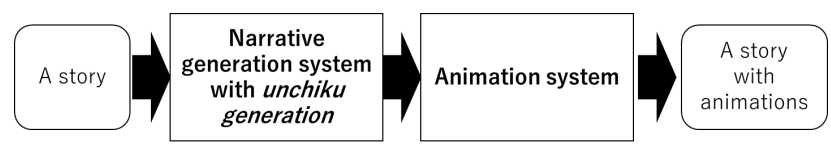

Fig. 4. The flow of a unchiku generation system with moving illustrations

The knowledge generation module takes a story and adds to it from the knowledge database. The unchiku generation module, using a story as its input, compares words in the story with information in the knowledge base, then generates an unchiku based on what it finds. Figure 2 is an example of knowledge retrieval for unchiku generation from Musume Dōjōji. Figure 3 is an input example showing how the module inserts the retrieved knowledge from Figure 2 into the Musume Dójoji story in Figure 3. We made two changes to the system presented in Section 2.1: one, the knowledge generation module now adds a symbol to the output sentence to clearly distinguish between events and knowledge, and two, it explicitly states that an animation will be inserted immediately after the pronouncement.

The following is the flow of unchiku generation:

1. The module receives a story from the user or story generator.

2. The module searches the knowledge for elements and keywords from the story to find relevant knowledge.

3. The system generates text presenting the retrieved knowledge.

4. The system inserts the generated knowledge into the story.

5. The system generates knowledge related to the generated knowledge.

6. The system inserts the generated knowledge into the story.

7. The system specifies the animation associated with the generated knowledge.

The knowledge retrieval and generation are repeated until there is no more relevant knowledge available. After that, the inserted animation will be related to the last generated knowledge.

The animation module receives the story from the unchiku generation module and generates a code for animation appropriate to the story. The module expresses the generated code and story as an animation as described in Section 2.
In the text representation, events are shown in black and insights in red. An animation is inserted at the end of the inscription.

\section{Discussion}

Figure 4 depicts the unchiku with moving illustration generated based on Figure 3. The unchiku is related to Musume Dojjoji. The content is as follows:

The story about Dōjōji is Kyōganoko Musume Dōjōji. Kyōganoko musume dōjōji. It is a representative work of Shosagoto. It is a work played by representative onnagata such as Nakamura Utaemon VI and Bandō Tamasaburō V from the Showa period. An old legend leads to the kabuki dance Kyōganoko Musume Dōjōji through reading materials such as Buddhist narratives, Noh, and picture scrolls. For example, the scene of Ranbyōshi is as follows: hito: Shirabyōshi Hanako; kokoro: daughter; huri: Shirabyōshi no mai; lyrics: Noh, gakki: hyousiita; scene: cherry tree (Dōjōji); ishō: red; kodougu: Chūkei, nikutai no; point: The legs. Figure 5 represents Ranbyōshi.

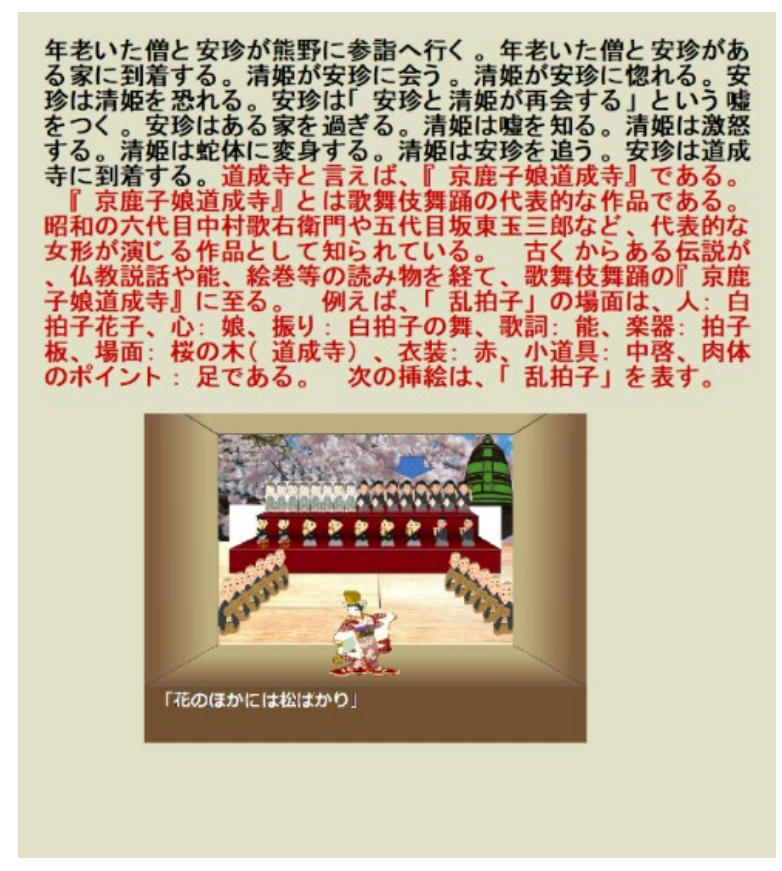

Fig. 5. Unchiku generation with moving illustration

In the future, we have two challenges for the system. First, we need to expand the Yunnan information we have in the knowledge base from our analysis of Kyoganoko 
Musume Dōjōji. ${ }^{11,12,13,14}$ Second, we need to expand the animations. We have created animations for Dōjōji, ${ }^{13,14}$ and our goal is to use those animations.

\section{Conclusion}

We have developed an advanced explanationgeneration system with two functions using Musume Dōjoji as our test model. First, the system inserts an unchiku explanation into a story. Second, it generates an animation to explain the unchiku. These two functions combine to deliver a more fully fleshed out explanation of the narrative.

\section{Acknowledgement}

This study was supported by JSPS KAKENHI, $18 \mathrm{~K} 18509$.

\section{References}

1. T. Ogata, Toward an Integrated Approach to Narrative Generation: Emerging Research and Opportunities, IGI Global, PA, USA, 2020.

2. T. Ogata, Internal and External Narrative Generation Based on Post-Narratology: Emerging Research and Opportunities, IGI Global, PA, USA, 2020.

3. J. Ono, K. Fukuda, M. Kawai, and T. Ogata., Considering unchiku generation mechanism through system implementation, Proc. of the 37th Annual Meeting of Japanese Cognitive Science Society, Japan, Tokyo, 2020, pp. 776-786.

4. J. Ono and T. Ogata, Unchiku Generation Using a Narrative Explanation Mechanism. In E. Ishita, N. L. S Pang \& L. Zhou (Eds.) Digital Libraries at Times of Massive Societal Transition (LNCS 12504), pp. 240-247. Switzerland: Springer Nature.

5. G. Genette, Narrative discourse: An essay in method (J. E. Lewin, Trans.), Cornell University Press, NY, 1972.

6. T. Akimoto, and T. Ogata, Towards a discourse mechanism in narrative generation system: Proposal of a System Introducing Narrative Discourse Theory and Reception Theory, Cognitive Studies, 20(4), 2013, pp. 396-420.

7. T. Ogata, Kabuki ni mukete (1): Shiisei to henshūsei no monogatari kara tajūsei to jitsuzon no monogatari he [Toward kabuki (1): From narratives of arbitrariness and editing to narratives of multiplicity and real existence], in Jōhō monogatariron: Jinkōchinō, ninchi, shakai katei to monogatari seisei [Informational narratology: Artificial intelligence/cognition/social process and narrative generation], eds. T. Ogata, Y. Kawamura and A. Kanai, Hakutō Shobō, Tokyo, Japan, 2018, pp. 187-208.
8. T., Ogata, Kabuki ni mukete (2): Tajū monogatari kōzō no shosō [Toward kabuki (2): Aspects of multiple narrative structures]. in Jōhō monogatariron: Jinkōchinō, ninchi, shakai katei to monogatari seisei [Informational narratology: Artificial intelligence/cognition/social process and narrative generation], eds. T. Ogata, Y. Kawamura and A. Kanai, Hakutō Shobō, Tokyo, Japan, 2018, pp. 209-244.

9. T. Ogata, Kabuki as Multiple Narrative Structures and Narrative Generation, in Post-Narratology Through Computational and Cognitive Approaches, eds. T. Ogata and T. Akimoto, IGI Global, PA, USA, 2019, pp. 192-275.

10. T. Ogata, Kabuki as a synthetic narrative: Synthesis and expansion. in Internal and external narrative generation based on post-narratology: Emerging research and opportunities, T. Ogata, IGI Global, PA, USA, 2019, pp. 315-403.

11. M. Kawai and T. Ogata, An analysis of Kyōganoko Musume Dōjōji for the generation of the staging structures of Kabuki from narrative plots, SIG-LSE Proc., 63, 2019, pp. 25-61.

12. M. Kawai and T. Ogata, Analyzing the stage performance structure of Kabuki-dance "Kyōganoko Musume Dōjōji", Proc. of the 34th Annual Conference of the Japanese Society for Artificial Intelligence, 2020, 3D1-OS-22a-04.

13. M. Kawai, J. Ono and T Ogata, The Stage Structure of a Kabuki-dance: Survey, Analysis, and Representation of Kyoganoko Musume Dojoji, Proc. of the 37th Japanese Cognitive Science Society, 2020, pp. 776-785.

14. M. Kawai, J. Ono and T. Ogata, Dual Story Generation Based on Love and Extreme Emotions, Proceedings of 2020 The 3rd International Conference on Computational Intelligence and Intelligent Systems, 2020, pp. 9-10.

15. T. Akimoto, S. Imabuchi, J. Endo, J. Ono, Y. Kurisawa, M. Kamada and T. Ogata, Development of a generation / expression system of narratives in the style of a folk tale, KOSERUBE version 1, Transactions of the Japanese Society for Artificial Intelligence, 28(5), 2013, pp. 442456.

16. P. Gervás, Propp' s Morphology of the Folk Tale as a Grammar for Generation, Workshop on Computational Models of Narrative, 2013, pp. 106-122.

17. K. L. Koay, D. S. Syrdal, K. Dautenhahn, and M. L. Walters, A narrative approach to human-robot interaction prototyping for companion robots, Journal of Behavioral Robotics, 11(1), 2020, pp. 66-85.

18. T. Watanabe, Musume Dōjōji, Shinshindo, Tokyo,1986.

19. Y. Kineie, Syamisenbunkahu nagauta Kyōganoko Musume Dōjoji, Hougakusya, Tokyo, 1952.

20. Kyōganoko Musume Dōjōji, Bandō Tamasaburō butō shū Vol.1 (DVD), Syotsiku Home Video, Tokyo, 2003. 